\title{
Physical, Proximate and Anti-nutritional Composition of African yam bean (Sphenostylis stenocarpa) Seeds Varieties
}

\author{
Ghaniyah O. Ajibola ${ }^{1} \&$ Abiodun A. Olapade ${ }^{1}$ \\ ${ }^{1}$ Department of Food Technology, Faculty of Technology, University of Ibadan, Ibadan, Nigeria \\ Correspondence: Ghaniyah O. Ajibola, Department of Food Technology, Faculty of Technology, University of \\ Ibadan, Ibadan, Nigeria. Tel: 234-8056-348-979. E-mail: ajibolaghaniyah@yahoo.com
}

Received: December 29, 2015

Accepted: January 27, 2016 Online Published: March 24, 2016

doi:10.5539/jfr.v5n2p67

URL: http://dx.doi.org/10.5539/jfr.v5n2p67

\begin{abstract}
The physical, proximate and anti-nutritional properties of five accessions of African yam bean (AYB) seeds (TSs 57, TSs 61, TSs 93, TSs 94 and TSs 116) obtained from Genetic Resource Centre (GRC) of International Institute of Tropical Agriculture (IITA) were studied and compared. This was aimed at unraveling the nutritional importance of this crop to enhance its production and utilisation. The physical properties investigated include seed size, length to diameter ratio, seed weight, percentage of seed coat, bulk density and loose density. Proximate composition and anti-nutritional factors such as saponin, oxalate, phytate, alkaloids, tannin, trypsin inhibitor and hydrogen cyanide of these accessions processed flours were also examined. The results of physical properties indicated significant differences $(\mathrm{P}<0.05)$ among the accessions except accessions TSs 93 and TSs 94 that did not differ in their lengths and diameters and also accessions TSs 61 and TSs 116 did not differ in their thicknesses. Results of proximate analysis revealed that crude fibre, fat and carbohydrate contents of the accessions were not significantly different from one another at $(\mathrm{P}<0.05)$ except TSs 94 that differed in its carbohydrate and TSs 116 also differed in its crude fibre from others. Meanwhile, in terms of anti-nutritional factors, there existed no significant difference in saponin contents but there were significant differences in oxalate, phytate, alkaloids, tannin, trypsin inhibitor and hydrogen cyanide among the accessions tested.
\end{abstract}

Keywords: accessions, african yam bean, anti-nutritional factors, physical and proximate

\section{Introduction}

Protein-energy malnutrition is one of the most serious health problems common in the developing countries (Food and Agriculture Organisation of the United Nations (FAO), 2000). Meanwhile, legumes are recognised as an economical source of calories and proteins, particularly for developing countries since their seeds contain high concentration of carbohydrates (50-67\%) and protein (23-25\%) (Olapade, Oluwole, \& Aworh, 2012). Studies have shown that the lesser known legumes together with other conventional legumes can be used for combating protein malnutrition prevalent in the third world (Arisa \& Aworh, 2007). Food-security and sustainability are serious global concerns in recent times. Moreover, many indigenous food crops of Africa which promise to reduce nutritional food insecurities are presently neglected and underutilised (Ajayi, 2011). African yam bean (AYB) is one of such underutilised crop with great genetic and economic potentials (Ajibade et al., 2005; Betsche, Azeke, Buening-Pfaue, \& Fretzdorff, 2005). It is a crop with tremendous nutritional potentials (Adewale and Odoh, 2013) and its economic potential has been recognised, especially in reducing malnutrition among Africans (Adewale, 2010).

AYB is an herbaceous leguminous and annual crop that contains bean seeds that are usually enclosed in a pod like cowpea. Each pod contains between ten and thirty seeds that may be of more than one colour. These pods are usually borne on a climbing stem with wide heart-shaped leaves; one at each node spaced apart along the stem (Asoiro \& Ani, 2011). Apart from the seeds, the plant also produces spindle shaped starchy tubers smaller in size than those of sweet potato. It takes between 5 to 8 months to mature (Nwodo \& Nwinyi, 2012) and these small underground tubers are of various sizes and shapes (Adewale \& Dumet, 2011). AYB is usually grown in West Africa particularly in Cameroon, Cote d'lvoire, Ghana, Nigeria and Togo. It is used extensively in various dietary preparations because of its potential for supplementing the protein requirement of many families throughout the year (Ajayi, 2011), though its seeds harbour vast genetic diversities for nutritive and anti-nutritive factors (Ajibade et al., 2005; Betsche, Azeke, Buening-Pfaue, \& Fretzdorff, 2005). AYB is a good source of 
protein, carbohydrate, vitamins and minerals. However, constraints to its cultivation and utilisation include presence of high concentrations of anti-nutritional factors such as trypsin inhibitor, phytate, tannin, oxalate and alkaloids and long cooking time (Nwokolo, 1987; Ajibade, Balogun, Afolabi, Ajomale, \& Fasoyiro, 2005; Fasoyiro, Ajibade, Omole, Adeniyan, \& Farinde, 2006). Ndidi et al. (2014) opined that processing reduced the level of anti-nutrients to their tolerable levels. Moreover, processing such as heating, soaking or fermenting has been used to lower anti-nutritional factors and improve their nutritional value (Onyeike, Ayalogu, \& Uzogara, 1995). According to Okonkwo, Njoku and Mbah (2013), AYB extract was found not to be toxic up to 5000 $\mathrm{mg} / \mathrm{kg}$, indicating the safety of the plant for both human and animal consumption. Furthermore, Onyeike (2012) opined that autoclaving AYB decreased the levels of cyanogenic glycosides, oxalates, tannins, saponins and trypsin inhibitors, which were further reduced by cooking to physiologically tolerable levels.

Despite these constraints, the demand of its seed grains for human consumption is linked to size and shape (Shahin, Symons, \& Poysa, 2006). This is due to the fact that various metric measurements of the seeds are very essential quantitative variables for determining size and shape of the seeds (S. Wyllie-echeverria, Coxfls, Chuchill, Brotherson, \& T. Wyllie-echeverria, 2003). Also, the knowledge of physical properties of seeds are essential parameters require in the designing of equipment necessary for harvesting and post-harvest handling, transportation and processing of agricultural produce into different consumable and marketable food items. Various types of unit operations such as cleaning, grinding and sorting are designed on the basis of these properties (Ojo \& Ade-Omowaye, 2015). The physical properties of legumes are, therefore important pre-requisites for the designing of equipment and facilities for harvesting, handling, conveying, separating, drying, aerating, storing and mechanical extraction of oil and other food processes (Oyebode, Ojo, \& Oshodi 2007).

For instance, in Nigeria, there is rarely any large-scale producer of AYB. As a result; most small-scale producers carry out these operations manually which are quite cumbersome and time consuming. Hence, this necessitates the assessment of physical properties, nutritive and anti-nutritive factors of the five accessions of AYB to reveal the importance of the crop, thereby improving the productivity and promoting the utilisation.

\section{Materials}

Five accessions of AYB were obtained from Genetic Resource Centre of IITA Ibadan, Oyo State, Nigeria. The seeds were cleaned to remove dirt and damaged seeds and were divided into two portions. The first portion was used to determine physical properties of the seeds while the other portion was processed into flours and used to determine proximate composition and anti-nutritional factors.

\section{Methods}

The physical properties of the five African yam bean accessions were determined as follows:

The seed size was determined as described by Kaushik, K. Kumar, S. Kumar and Roy, (2007) with slight modification. The seed length, seed diameter and seed thickness of 100 seeds were measured in millimeters using digital Vernier caliper. The average seed size was then calculated. The ratio between the seed length and diameter was estimated from the individual values of the length and diameter of the seeds as described by Omokhafe and Alika (2004). The 100 seed weights of the accessions were determined by randomly selecting, counting and weighing of seeds that have been previously cleaned using Soehnle professional weighing balance model 9230. The percentage of seed coat was also determined by dividing its weight of each accession with its corresponding seed weight. The bulk densities and loose densities of the five accessions of AYB seeds were determined using a $100 \mathrm{ml}$ measuring cylinder as described by Onwuka (2005a) with slight modification.

AYB flours were processed according to the method described by Okoye, Ezigbo and Animalu (2010). Proximate compositions of the samples were determined as described by AOAC (2005). The anti-nutritional factors such as saponin, oxalate, phytate, alkaloids, tannin, trypsin inhibitor, and hydrogen cyanide were determined. Phytate of the samples were determined using the Biphyrimidine colorimeter method as described by Onwuka (2005b) and tannin content of the samples were determined as tannic acid, following a procedure of Ajayi, (2011). Trypsin inhibitor was determined by spectrophotometric method as described by (Nwosu, 2011) while oxalate and saponin were determined using the methods of AOAC (1990). All the tests were done in triplicate and statistical analysis of the data was performed using analysis of variance and Duncan's Multiple Range Test procedures fixed at $\mathrm{P}=0.05$ was used to separate mean values. This was done using Statistical Package for Social Sciences, SPSS (windows version 20).

\section{Results and Discussion}

The physical properties of AYB seed accessions are depicted in Table 1. It was observed that the seeds sizes 
ranged from $7.95 \mathrm{~mm} \times 5.46 \mathrm{~mm} \times 5.82 \mathrm{~mm}$ to $8.21 \mathrm{~mm} \times 6.03 \mathrm{~mm}$ x $6.30 \mathrm{~mm}$, TSs 61 was the least while TSs 93 was the highest in size. It was observed from the accessions tested that the seed length was longer than the width and thickness but the difference between seed width and thickness was not consistent. This result was comparable to that of Adewale, Kehinde, Aremu, Popoola and Dumet (2010). The results of length to diameter showed that sample TSs 61 was the highest while TSs 116 was the least. It was revealed that 100 seeds weight was highest in TSs 94 (24.02 g) followed by TSs 57 (23.40 g), TSs $61(20.83 \mathrm{~g})$, TSs 93 (20.80 g) and TSs 116 $(20.74 \mathrm{~g})$ was the least. These results fall within the range obtained by Adewale and Udoh, (2013) of values (11.46-36.0 g). Also, the results of the bulk density and loose density were in the range $0.7428 \mathrm{gcm}^{-3}-0.8357$ $\mathrm{gcm}^{-3}$ and $0.6709 \mathrm{gcm}^{-3}-0.7681 \mathrm{gcm}^{-3}$ respectively. The bulk density values were lower than those obtained by Asoiro and Ani (2011) of values $\left(1.0179 \mathrm{gcm}^{-3}\right)$. The accession TSs 57 was the highest in bulk density, while TSs 116 was the highest in loose density while TSs 93 had the least value for both bulk density and loose density. The percentage seed coats obtained were in the range of $7.631 \%$ and $13.674 \%$. Accession TSs $93(13.674 \%)$ had the highest percentage seed coat while accession TSs 116 (7.631\%) had the least.

Table 1. Physical properties of five accessions of Sphenostylis stenocarpa seeds

\begin{tabular}{lllllllll}
\hline $\begin{array}{l}\text { AYB } \\
\text { Accessions }\end{array}$ & $\begin{array}{l}\text { Length } \\
(\mathrm{mm})\end{array}$ & $\begin{array}{l}\text { Diameter } \\
(\mathrm{mm})\end{array}$ & $\begin{array}{l}\text { Thickness } \\
(\mathrm{mm})\end{array}$ & $\begin{array}{l}\text { Length to } \\
\text { diameter }\end{array}$ & $\begin{array}{l}\text { Hundred } \\
\text { seed } \\
\text { weight }(\mathrm{g})\end{array}$ & $\begin{array}{l}\text { Seed } \\
\text { coat }(\%)\end{array}$ & $\begin{array}{l}\text { Bulk } \\
\text { density } \\
\left(\mathrm{gcm}^{-3}\right)\end{array}$ & $\begin{array}{l}\text { Loose } \\
\text { density } \\
\left(\mathrm{gcm}^{-3}\right)\end{array}$ \\
\hline TSs 57 & $8.15_{\mathrm{ab}}$ & $5.75_{\mathrm{b}}$ & $6.18_{\mathrm{ab}}$ & $1.42_{\mathrm{ab}}$ & $20.74_{\mathrm{c}}$ & $7.63_{\mathrm{d}}$ & $0.8356_{\mathrm{a}}$ & $0.7552_{\mathrm{a}}$ \\
TSs 61 & $7.95_{\mathrm{b}}$ & $5.46_{\mathrm{c}}$ & $5.82_{\mathrm{c}}$ & $1.47_{\mathrm{a}}$ & $20.81_{\mathrm{c}}$ & $7.85_{\mathrm{cd}}$ & $0.8011_{\mathrm{a}}$ & $0.7441_{\mathrm{b}}$ \\
TSs 93 & $8.21_{\mathrm{a}}$ & $6.03_{\mathrm{a}}$ & $6.30_{\mathrm{a}}$ & $1.38_{\mathrm{b}}$ & $20.83_{\mathrm{c}}$ & $8.19_{\mathrm{c}}$ & $0.6933_{\mathrm{c}}$ & $0.6710_{\mathrm{c}}$ \\
TSs 94 & $8.20_{\mathrm{a}}$ & $5.96_{\mathrm{a}}$ & $6.07_{\mathrm{b}}$ & $1.39_{\mathrm{b}}$ & $23.40_{\mathrm{b}}$ & $10.84_{\mathrm{b}}$ & $0.8010_{\mathrm{a}}$ & $0.7507_{\mathrm{a}}$ \\
TSs 116 & $7.95_{\mathrm{b}}$ & $5.60_{\mathrm{c}}$ & $5.85_{\mathrm{c}}$ & $1.43_{\mathrm{ab}}$ & $24.02_{\mathrm{a}}$ & $13.67_{\mathrm{a}}$ & $0.7076_{\mathrm{b}}$ & $0.7679_{\mathrm{a}}$ \\
\hline
\end{tabular}

Values are means of three determinations. Means with the same subscript along the column are not significantly different $(\mathrm{P}<0.05)$.

Table 2 showed the result of proximate composition of processed African yam bean flours of the five accessions. The highest moisture content was observed in TSs 57 (14.95\%), followed by TSs 61 (13.87\%), while the lowest percentage moisture content was obtained in TSs 93 (12.19\%). The highest percentage crude protein of $26.68 \%$ was obtained from TSs 94 while the lowest crude protein was recorded in accession TSs $57(22.72 \%)$. These values fall within the range reported by Obiakor (2008) and Aburime (2012) of values $21-29 \%$ and $19.96-31.87 \%$ respectively. There were no significant differences $(\mathrm{P}<0.05)$ exist between the percentage crude protein, fibre, and carbohydrate of the five accessions except accession TSs 116 that was significantly different in terms of crude fibre and also accession TSs 94 was significantly different from others in terms of its crude protein and carbohydrate. Meanwhile, there existed no significant difference in fat content among all the accessions tested. The range of carbohydrate content obtained in this study compared with the value recorded by Ojukwu, Olawuni, Ibeabuchi and Amandikwa (2012) of value (58.47\%).

Table 2. Proximate composition of five accessions of processed African yam bean flours

\begin{tabular}{|c|c|c|c|c|c|c|}
\hline $\begin{array}{l}\text { Accession } \\
\text { Number }\end{array}$ & Moisture (\%) & $\begin{array}{l}\text { Crude } \\
\text { Protein (\%) }\end{array}$ & $\begin{array}{l}\text { Crude } \\
(\%)\end{array}$ & $\begin{array}{ll}\text { Fat } & \\
& \text { Ash (\%) } \\
\end{array}$ & $\begin{array}{l}\text { Crude Fibre } \\
(\%)\end{array}$ & $\begin{array}{l}\text { Carbohydrate } \\
(\%)\end{array}$ \\
\hline TSs 57 & $14.95_{\mathrm{a}}$ & $22.72_{b}$ & $2.03_{\mathrm{a}}$ & $1.01_{\mathrm{c}}$ & $2.94_{\mathrm{a}}$ & $59.29_{\mathrm{a}}$ \\
\hline TSs 61 & $13.87_{\mathrm{a}}$ & $23.94_{b}$ & $1.67_{\mathrm{a}}$ & $1.90_{\mathrm{b}}$ & $2.52_{\mathrm{a}}$ & $58.62_{\mathrm{a}}$ \\
\hline TSs 93 & $12.19 \mathrm{~b}$ & $24.27_{\mathrm{b}}$ & $1.91_{\mathrm{a}}$ & $2.40_{\mathrm{a}}$ & $2.37_{\mathrm{a}}$ & $59.22_{\mathrm{a}}$ \\
\hline TSs 94 & $13.19_{b}$ & $26.68_{a}$ & $1.93_{\mathrm{a}}$ & $1.92_{\mathrm{ab}}$ & $2.51_{\mathrm{a}}$ & $56.28_{\mathrm{b}}$ \\
\hline TSs 116 & $12.30_{\mathrm{b}}$ & $23.95_{b}$ & $1.86_{a}$ & $2.09_{\mathrm{ab}}$ & $2.03_{\mathrm{ab}}$ & $59.79_{a}$ \\
\hline
\end{tabular}

Values are means of three determinations. Means with the same subscript along the column are not significantly different $(\mathrm{P}<0.05)$. 
The results of anti-nutritional factors of the five accessions were shown in Table 3. It was observed that TSs 93 had the least anti-nutritional factors in all the parameters tested except in alkaloids and hydrogen cyanide where TSs 57 was least while TSs 61 had highest anti-nutritional factors in all the parameters tested except in saponin and hydrogen cyanide where TSs 94 had highest values. The values of anti-nutritional factors obtained in this work were lower than those obtained from Nwosu, (2013) and these values fall within the permissible limit based on Ndidi, C. U. Ndidi, O., Abbas, Aliyu, Francis, and Oche (2014).

Table 3. Anti-nutritional factors of processed African yam bean flours

\begin{tabular}{llllllll}
\hline $\begin{array}{l}\text { Accession } \\
\text { Number }\end{array}$ & $\begin{array}{l}\text { Saponin } \\
(\%)\end{array}$ & $\begin{array}{l}\text { Oxalate } \\
(\%)\end{array}$ & $\begin{array}{l}\text { Phytate } \\
(\%)\end{array}$ & $\begin{array}{l}\text { Alkaloids } \\
(\%)\end{array}$ & Tannin $(\%)$ & $\begin{array}{l}\text { Trypsin } \\
(\text { TIU/mg) }\end{array}$ & $\begin{array}{l}\text { HCN } \\
(\mathrm{mg} / \mathrm{kg})\end{array}$ \\
\hline TSs 57 & $0.101_{\mathrm{a}}$ & $0.0056_{\mathrm{a}}$ & $0.0136_{\mathrm{a}}$ & $0.189_{\mathrm{b}}$ & $0.0026_{\mathrm{b}}$ & $3.05_{\mathrm{b}}$ & $6.86_{\mathrm{c}}$ \\
TSs 61 & $0.123_{\mathrm{a}}$ & $0.0070_{\mathrm{a}}$ & $0.0145_{\mathrm{a}}$ & $0.252_{\mathrm{a}}$ & $0.0059_{\mathrm{a}}$ & $3.32_{\mathrm{a}}$ & $7.43_{\mathrm{b}}$ \\
TSs 93 & $0.090_{\mathrm{a}}$ & $0.0029_{\mathrm{b}}$ & $0.0126_{\mathrm{b}}$ & $0.204_{\mathrm{b}}$ & $0.0015_{\mathrm{b}}$ & $2.22_{\mathrm{c}}$ & $7.39_{\mathrm{b}}$ \\
TSs 94 & $0.129_{\mathrm{a}}$ & $0.0034_{\mathrm{b}}$ & $0.0127_{\mathrm{b}}$ & $0.274_{\mathrm{a}}$ & $0.0016_{\mathrm{b}}$ & $2.40_{\mathrm{c}}$ & $7.76_{\mathrm{a}}$ \\
TSs 116 & $0.112_{\mathrm{a}}$ & $0.0044_{\mathrm{b}}$ & $0.0127_{\mathrm{b}}$ & $0.216_{\mathrm{b}}$ & $0.0023_{\mathrm{b}}$ & $2.92_{\mathrm{b}}$ & $6.48_{\mathrm{d}}$ \\
\hline
\end{tabular}

Values are means of three determinations. Means with the same subscript along the column are not significantly different $(\mathrm{P}<0.05)$.

\section{Conclusion}

The assessment of physical properties, proximate composition and anti-nutritional factors of AYB accessions will play a major role in designing, constructing and developing equipment that will enhance good handling, harvesting, processing, transportation practices and desirable marketing strategies that will promote the utilisation of crop. This research has established that there existed significant differences in the nutritional and anti-nutritional values of AYB seeds except fat and saponin content that were not significantly different from one accession to another. The protein contents of the accessions were quite high, therefore, it compared well with other legumes and made it a good substitute and it will help relieve the heavy demand on major legumes. The high protein and carbohydrate contents of AYB could be of great value for incorporating into various starchy and traditional dishes for both children and adults to alleviate protein energy malnutrition in the developing countries. The tested accessions contain a low anti-nutritional factor which means that these accessions could solve the anti-nutritional factor constraints in the utilisation of AYB seeds. The result of this research revealed the importance of the crops and could encourage farmers to engage in the cultivation of the crop. Hence, enhancing the optimum utilisation and maximisation of the potentials of the seeds will contribute to the efforts of preventing the seeds from extinction.

\section{Acknowledgements}

The authors appreciated the efforts of Genetic Resource Centre of the International Institute of Tropical Agriculture for the provision of African yam bean seeds used for this research.

\section{References}

Aburime, L. C. (2012). Effect of different processing methods on the chemical composition of African yam bean (Sphenostylis stenocarpa) flours and organoleptic characteristics of their gruels. (Unpublished master's thesis). University of Nigeria Nsukka, Nigeria.

Adewale, B. D., Kehinde, O. B., Aremu, C. O., Popoola, J. O., \& Dumet, D. J. (2010). Seed Metrics for Genetic and Shape Determinations in African yam bean [Fabaceae] (Sphenostylis stenocarpa Hochst. Ex. A. Rich) Harms). African Journal of Plant Science, 4(4), 107-115.

Adewale, B. D., \& Odoh, N. C. (2013). A Review on Genetic Resources, Diversity and Agronomy of African Yam Bean (Sphenostylis stenocarpa (Hochst. Ex A. Rich.) Harms): A Potential Future Food Crop. Sustainable Agriculture Research, 2(1), 32-43. http://dx.doi.org/10.5539/sar.v2n1p32

Ajayi, A. O. (2011) Sustainable Dietary Supplements: An Analytical Study of African Yam Bean-Sphenostylis Sternocarpa and Corn-Zea Maiz. European Journal of Experimental Biology, 1 (4), 189-201.

Ajibade, S. R., Balogun, M. O., Afolabi, O. O., Ajomale, K. O., \& Fasoyiro, S. B. (2005). Genetic Variation in 
Nutritive and Antinutritive Content of African yam bean. Trop. Sci., 5, 144-148. http://dx.doi.org/10.1002/ts.14

AOAC. (1990). Official Methods of Analysis (15th Ed.). Association of Official Analytical Chemists, Washington, DC, USA.

AOAC. (2005). Official Methods of Analysis (18th Ed.). Association of Official Analytical Chemists. Washington D.C., USA.

Arisa, N. U., \& Aworh, O. C. (2007). Production, Quality Assessment and Acceptability of African yam bean Sphenostylis stenoscarpa sauce. Journal of Food Processing and Preservation, 31, 771-778. http://dx.doi.org/10.1111/j.1745-4549.2007.00152.x

Asoiro, F. U., \& Ani, A. O., (2011). Determination of Some Physical Properties of African Yam Beans. The Pacific Journal of Science and Technology, 12(1).

Betsche, T., Azeke, M., Buening-Pfaue, H., \& Fretzdorff, B., (2005). Food safety and security: Fermentation as a tool to improve the nutritional value of African yam bean, in Conference proceeding from the International Agricultural Research for development, October 2005, Stuttgart-Hohenheim (pp. 1-5).

FAO. (2000). Protein quality evaluation (Report of a joint FAO or WHO expert consultation held in Bethesda, MD, USA, Dec 1989) FAO, Rome, Italy.

Fasoyiro, S. B., Ajibade, S. R., Omole, A. J., Adeniyan, O. N., \& Farinde, E. O. (2006). Proximate, Minerals and Antinutritional Factors of some Under-utilized Grain Legumes in South-Western Nigeria. Nutr. Food Sci., 36(1), 18-23. http://dx.doi.org/10.1108/00346650610642151

Kaushik, N., Kumar, K., Kumar, S., Kaushik, N., \& Roy, S. (2007). Genetic Variability and Divergence Studies in Seed Traits and Oil Content of Jatropha (Jatropha curcas) Accessions. Biomass and Bioenergy, 31, 497-502. http://dx.doi.org/10.1016/j.biombioe.2007.01.021

Ndidi, U. S., Ndidi, C. U., Abbas, O., Aliyu, M., Francis, G. B., \& Oche, O. (2014). Proximate, antinutrients and mineral composition of raw and processed (Boiled and Roasted) Sphenostylis stenocarpa seeds from Southern Kaduna, Northwest Nigeria. http://dx.doi.org/10.1155/2014/280837

Nwokolo, E. (1987). A Nutritional Assessment of African yam bean Sphenostylis stenocarpa (Hochst ex A. Rich) and Bambara groundnut Voandzeia subterranea L. J. Sci. Food Agric., 41, 123-129. http://dx.doi.org/10.1002/jsfa.2740410205

Nwosu, J. N. (2011). The Effects of Processing on the Anti-nutritional Properties of Oze Bosqueia Angolensis Seed. Journal of American Science, 71, 1-6.

Nwosu, J. N. (2013). Evaluation of the Proximate Composition and Antinutritional Properties of African yam bean (Sphenostylis sternocarpa) Using Malting Treatment. International Journal of Basic and Applied Sciences, 2(4), 157-169.

Obiakor, P. N. (2008). Effect of fermentation on the nutrient and antinutrient composition of african yam bean seeds and pearl millet grains. Annual conference and scientific meeting, Nutrition Society of Nigeria, 30, 60-70.

Ojukwu, M, Olawuni, I. A, Ibeabuchi, C., \& Amandikwa, C. (2012). Physical, proximate and functional properties of 'Nsama' A local variety of African yam bean (sphenostylis stenocarpa) grown in southern states in Nigeria. African Journal of Food Science and Technology, 3(10), 260-267.

Ojo M. A., \& Ade-Omowaye B. I. O., (2015). Some Functional and Physical Properties of Selected Underutilised Hard-To-Cook Legumes in Nigeria. American Journal of Food Science and Nutrition, 2(5), pp. 73-81.

Okoye, J. I., Ezigbo, V. O., \& Animalu, I. L. (2010). Development and Quality Evaluation of Weaning Food Fortified with African Yam Bean (Sphenostylis stenocarpa) flour. Continental J. Agricultural Science, 4, $1-6$.

Olapade, A. A., Oluwole, O. B., \& Aworh, O. C. (2012). Physico-chemical properties and consumer acceptance of instant cowpea (Vigna unguiculata) powder for complementary food. African J. Food Sci. Technol., 3, 102-106.

Omokhafe, K. O., \& Alika, J. E., (2004). Clonal variation and correlation of seed characters in Hevea brsiliensis Muell. Arg. Ind. Crops Prod., 19, 175-184. http://dx.doi.org/10.1016/j.indcrop.2003.09.004 
Onwuka, G. I. (2005a). Functional properties in: Food analysis and instrumentation (pp. 134-135). Naphtali Prints Lagos.

Onwuka, G. I. (2005b). Corporative studies on the winning potentials of black tamarind, local grape fruit and exotic apple. Department of Food Science and Technology, Michael Okpara University of Agriculture. Journal of Food Technology, 4(4), 350-353.

Onyeike, E. U., Ayalogu, E. O., \& Uzogara, S. G. (1995). Influence of heat processing of African yam bean seed (Sphenostylis stenocarpa) flour on the growth and organ weights of rats. Plant Foods for Human Nutrition, 48, 85-93. http://dx.doi.org/10.1007/BF01088303

Oyebode, E. T., Ojo, M. A., \& Oshodi, A. A. (2007). Physico chemical properties and in-vitro protein digestibility of flours and protein isolate from Adenopus breviflorus Benth seed. Science Focus, 12(1), 28-34.

Shahin, M. A., Symons, S. J., \& Poysa, V. W. (2006). Determining soyabean seed size uniformity with image analysis. Biosys. Engine., 94, 191-198. http://dx.doi.org/10.1016/j.biosystemseng.2006.02.011

Wyllie-Echeverria, S, Coxfls, P. A, Chuchill, A. C, Brotherson, J. D., \& WyllieEcheverria, T. (2003). Seed size variation within Zostera marina L. (Zosteraceae). Bot. J. Linn. Soc., 142, 281-288. http://dx.doi.org/10.1046/j.1095-8339.2003.00180.x

\section{Copyrights}

Copyright for this article is retained by the author(s), with first publication rights granted to the journal.

This is an open-access article distributed under the terms and conditions of the Creative Commons Attribution license (http://creativecommons.org/licenses/by/3.0/). 